\title{
SPORTO KLUBŲ VYSTYMO IR VARTOTOJŲ POREIKIŲ DERMĖ: MOKSLINIŲ INTERESŲ ASPEKTAS
}

\author{
Diana Komskienė, Biruta Švagždienè \\ Lietuvos sporto universitetas, Kaunas, Lietuva
}

\section{ANOTACIJA}

Viena pagrindinių sėkmingos sporto klubų vystymo ir vartotojų poreikių dermès prielaidų - vartotojų poreikių ir lūkesčių tenkinimas gerinant teikiamų paslaugų kokybę. Paslaugų kokybė skatina vartotojų lojalumą, užtikrina potencialių vartotojų pritraukimą, darbuotojų pasitenkinimą ir teigiamo įvaizdžio formavimą rinkoje. Straipsnyje, vadovaujantis atliktų tyrimų duomenimis, pateikiami sporto klubų vystymo ir vartotojų poreikių dermès veiksniai. Aptariama, kokiu mastu tai lemia veiklos ypatumus. Manoma, kad vienas svarbiausiut veiksnių, skatinančių sporto klubų vystymąsi ir konkurenciją tarp organizacijų, padedančių išsilaikyti arba užkariauti rinkas, yra vartotojų poreikių patenkinimas. Visgi sporto klubų vartotojų poreikiai dažniausiai analizuojami kokybės aspektu (Bodet, 2006). Kokybė formuoja sporto klubų ìvaizdi, turi tiesioginės įtakos veiklos produktyvumui, pelno augimui, vartotojo pasitenkinimui.

Tyrimo tikslas - atskleisti sporto klubo vystymo ir vartotojų poreikių dermę mokslinių interesų aspektu. Tyrimo metodai: mokslinès literatūros šaltinių analizè, sisteminimas ir apibendrinimas. Atliktas kokybinis tyrimas. Taikyta turinio analizè. Buvo tiriama sporto klubų teikiamu paslaugu poreikis, lojalumas klubui, vartotoju poreikiai ir motyvacija. Sporto klubu vystymas(-is) yra paslaugos vartotojo suvokiama nauda, kurią sukuria paslaugos teikejjas, naudodamas ivairias komunikacines ir rèmimo priemones. Visos sporto klubu paslaugos gali būti skirstomos $\mathfrak{i}$ tris grupes: 1) pagrindinès paslaugos; 2) papildomos periferinès paslaugos; 3) pagalbinès, arba specialios, ir poilsio organizavimo paslaugos. Be to, reikia nuolat tirti rinką, siekiant geriau suprasti vartotojų lūkesčius ir tenkinti jų poreikius.

Raktažodžiai: sporto klubas, paslauga, pasitenkinimas, įvaizdis, motyvacija.

\section{IVADAS}

Straipsnio aktualumas ir naujumas. Šių dienų sporto klubų vystymo ir vartotojų poreikių dermė kaip ištirta tarpdisciplininė sritis atskleidžia mokslinių požiūrių ívairovę. Vieni tyrèjai tvirtina, kad skirtingose šalyse vyksta vakarietiška, arba vadinamoji globali, sporto klubu plètra. Kiti tyrèjai oponuoja šiai nuomonei teigdami, kad globali plètra tèra mitas, nes nepaisant didèjančios rinkų globalizacijos vis daugiau imonių, siekiančių sėkmingai jose dalyvauti, turi atsižvelgti i vietos rinkos ypatumus ir prie jų derinti vartotojų poreikius. Mokslinès studijos rodo, kad sporto klubų vystymo ir vartotojų poreikių dermè yra vienas iš veiksnių, lemiančių individų elgseną, santykių suvokimą, ipročius, prekès ženklų, rinkodaros komunikacijų sąveikas. Neabejotina, kad šio veiksnio raiška tampa svarbiu tyrimų objektu.

Problema. Susidomėjimas sporto klubų vystymu ir vartotoju poreikiais didèja, todèl tyrimu šia tema daugèja. Apie tai liudija ir LSU studentu atlikti sporto klubu veiklos bei vartotoju poreikių tyrimai, ir kiti Lietuvoje atliktu tyrimų rezultatai. Tokie tyrimai buvo atlikti Sabonio klubo 
Sveikatingumo centre, Vilniaus universiteto Medicinos fakulteto studentai atliko tyrimus tema Sporto klubq lankančiu moteru socialinè padètis, bendra sveikatos būklè ir sportavimo motyvacija (Marcinkutè, Ambrazevičius, Rainys 2007), UAB BGI consulting parengè Sveikatingumo ir poilsio kompleksu poreikio ir plètros Lietuvoje studija (2007), tyrimu grupe RAIT ir reklamos planavimo firma Universalmccann atliko rinkos analizę. Visi šie tyrimai patvirtina temos problemiškumą ir leidžia suformuluoti straipsnyje nagrinejjamą problemą - kokie yra sporto klubų vystymo ir vartotojų poreikių veiksniai ir kokiu mastu tai lemia sporto klubų veiklos ypatumus?

Tinkamo darbuotojo pasirinkimas ir sporto klubo veiklos politikos formavimas yra pirmieji veiklos etapai siekiant teisingai nustatyti vartotoju poreikius. Jei pasirenkamas tinkamas darbuotojas, t. y. pakankamai kompetentingas ir kvalifikuotas, jis gali kokybiškai atlikti darbą, o motyvavimo priemonès padeda didinti jo darbo efektyvumą. Viena iš priežasčių, trukdančiu išlaikyti savo vartotojus, yra nemokèjimas suderinti jų lūkesčiu su organizacijos galimybèmis ir vidinès komunikacijos stoka (Dževeckytė, 2007). Todėl pirmas darbdavio uždavinys - išsiaiškinti darbuotojo poreikius. M. Kaliprasad (2006), apibendrindamas įvairias poreikių teorijas, nurodo tokius pagrindinius poreikius pagal svarbą: darbo užmokestis, saugumas, draugiškas kolektyvas, pripažinimas ir tinkamas ivertinimas už atliktą darbą, prasmingas darbas, paaukštinimo galimybè, patogi, saugi ir patraukli darbo aplinka, kvalifikuotas ir teisingas vadovavimas, protingi isakymai ir užduotys. Tokie tyrimai organizacijoje visuomet duoda teigiamų rezultatų, nes nežinodamas poreikių vadovas negali formuoti ir efektyvios motyvavimo sistemos. K. D. Woodard-Chavez (2003) teigimu, patenkinti vartotojai išlieka lojalūs įmonei net ir esant didesnèms paslaugų kainoms nei kitur. L. Carruba (2004) atkreipia dėmesí, kad sporto klubas samdo, moko darbuotojus ir valdo vartotojus vadovaudamasis tokia filosofija: „Siek pirmiausia suprasti, o paskui - būti suprastas“. Tai atlieka per atvirus interviu, dalydami klausimynus mokymų metu, kad galètų ịvertinti darbuotojų stiprybes ir silpnybes, reguliariai suteiktų galimybę išsakyti savo nuomonę ir susirūpinimą. Taigi apibendrinant galima teigti, kad žmogiškiesiems organizacijos ištekliams valdyti reikia formuoti tam tikrą politika, nuolat atlikti tyrimus poreikiams ir lūkesčiams išsiaiškinti bei sukurti motyvavimo sistema, pagrịstą tyrimų rezultatais.

Tyrimo tikslas - atskleisti sporto klubo vystymo ir vartotojų poreikių dermés ypatumus.

Tyrimo metodai: mokslinès literatūros šaltinių analizè, sisteminimas ir apibendrinimas.

Tyrimo organizavimas. Atliktas kokybinis tyrimas. Taikyta turinio analizè. Buvo tiriama sporto klubų teikiamų paslaugų poreikis, lojalumas klubui, vartotojų poreikiai ir motyvacija.

\section{TEORINIS PAGRINDIMAS}

Šių dienų gyvenimas dažnai susijęs su ịtemptu protiniu darbu, reikalaujančiu psichinių, o ne fiziniu jègų, sukeliančiu nervinę itampą, dažnai - net stresines situacijas. Kovojant su šiais neigiamais visuomenès veiklos reiškiniais ir siekiant užtikrinti žmonių gyvenimo kokybę vis dažniau akcentuojama sporto ir fizinė veikla. Tačiau socialinis sporto vaidmuo vis mažèja, t. y. kaip laisvalaikio praleidimo forma jis praranda savo pirmines vertybes, o svarbesnè tampa ,pergalè bet kokiomis 
priemonėmis“ ir konkurencinė rinka (Garrigou, 2008). Todèl darosi vis sudėtingiau išlaikyti lojalius klientus, o kartu - nuolat pritraukti naujus, kad verslas vystytųsi.

Sporto irenginių ar klubų kūrèjai, steigèjai ar vadovai turi gebèti valdyti daugeli veiklų, kad investicijos atsipirktų. Tai gali užtikrinti teisingas vadybos procesas, todèl, be gebejjimo atlikti planavimo, vadovavimo, kontrolès ir organizavimo funkcijas, vadovui būtina turèti lyderio savybių ir taikyti jas savo darbe (Chelladurai, 2001; Appleby, 2003; Sawyer, Smith, 1999). Lyderio savybės, tiesiogiai susijusios su vadovo veikla, t. y. gebèjimas aiškiai apibrěžti užduotis, planuoti, organizuoti, kontroliuoti, vertinti, motyvuoti, rodyti pavyzdi, gali būti išugdytos (Watt, 2003; Chelladurai, 2001). Šių dienu vadovams patariama analizuoti aplinkybes ir, atsižvelgus i jas bei pasinaudojus ivvairių mokyklų idėjomis, ieškoti tinkamiausio valdymo technikų derinio (Appleby, 2003). Chelladurai (2001) atkreipia dèmesi $\mathfrak{i}$ tai, kad viena iš pagrindinių sporto organizacijos veiklų yra ne tik materialinių, bet svarbiausia - žmogiškujų išteklių, apimančių ir klientus, ir savanorius, valdymas. Autoriaus teigimu, paslauga negali būti teikiama aktyviai nedalyvaujant klientui. Klientų požiūris ị sportą ir atsidavimą gali būti skirtingas, todèl motyvuoti klientus, igyti jų prielankumą yra tikras iššūkis paslaugų teikèjams. Ne mažiau svarbu yra gebėti motyvuoti savanorius, nes jų motyvai ir elgsena skiriasi nuo apmokamų darbuotojų, o svarba ir indèlis i sporto industriją yra milžiniškas (Chelladurai, 2001; Watt, 2003; Brooks, 1994, Schlesinger, Nagel, 2013).

Sporto organizacija yra kuriama klientams, arba dalyviams, pritraukti. Todèl viena svarbiausių veiklų sporto organizacijoje - išsiaiškinti klientų lankymosi, sportavimo motyvus ir lūkesčius, kad būtų galima teisingai organizuoti paslaugas, valdyti personalą ir siekti organizacijos tikslų. To pasiekti padeda rinkodaros veiklos, glaudžiausiai susijusios su vartotojų pasitenkinimo teorija, nes kuriant naujus ir tobulinant esamus produktus reikia orientuotis ne tiek i produktą, kiek i vartotoją arba rinką (Appleby, 2003). I vartotoją orientuota bendrovè (angl. customer-oriented company) yra tokia, kuri, prieš kurdama rinkodaros strategijas ir suteikdama tikslinei vartotojų grupei didesnę vertę, didžiausią dèmesi sutelkia ị vartotojo poreikius (Kotler ir kt., 2003).

Vartotojų poreikių ir lūkesčių suvokimas bei jų socialinių duomenų analizė yra esminiai norint tinkamai atlikti rinkodaros veiklą ir yra efektyviai valdyti ịrengini (Westerbeek et al., 2006). Remiantis šia apibrèžtimi ir P. Chelladurai (2001) nuomone, klientų valdymas yra susijęs su žmogiškuju išteklių valdymu ir valdymu rinkodaros požiūriu. Atsieti juos sunku, nes vienas su kitu yra gana stipriai susiję (Garrigou, 2008).

Apibendrindamas daugelio autorių nuomones P. Chelladurai (2001) pateikia toki vartotojų motyvacijos skirstymą:

- Malonumų paieška. Žmonès dalyvauja sportinèje ar fizinėje veikloje (pavyzdžiui, lanko aerobikos užsièmimus), nes jiems tai paprasčiausiai patinka. Šiuos klientus pritraukti lengviau, nes juos skatina vidinè motyvacija - jiems malonumo teikia pats dalyvavimas.

- Igūdžių poreikis. Dalyvauti sportinèje ar fizinèje veikloje skatina troškimas igyti fizinių igūdžių. Žmonès gali nukreipti savo energiją igūdžiams tobulinti užsiimdami nuolatine 
energinga fizine veikla. Tokiems klientams gali būti naudinga organizuota veikla, pavyzdžiui, stovyklos, seminarai, kur mokoma taikyti igūdžius įvairiose sporto šakose.

- Tobulumo poreikis. Žmonès gali dalyvauti sportinèje ar fizinèje veikloje, nes siekia tobulumo šioje srityje (Chelladurai, 2001; Bredemeier, Shields, 2006). Tobulumo poreikis dažnai siejamas su pastangomis laimèti varžybose, pagerinti savo paties, kitų žmonių ar varžovų rezultatus. Šiems žmonėms siekis igyti meistriškumo igūdžių ir yra tobulumo poreikis (Chelladurai, 2001);

- Sveikatingumo / sportiškumo siekimas. Kai kurie žmonės dalyvauja sportinëje ir fizinëje veikloje dažniausiai dèl naudos, susijusios su sveikata, pavyzdžiui, norėdami atrodyti sportiškai, sumažinti stresą, siekdami ilgaamžiškumo. Tai gali būti žmonès, kurie ir dabar yra sportiški, sveiki, bet nori kuo ilgiau tokie būti. Tokių žmonių motyvai gali būti priskiriami palaikomiesiems motyvams. O žmonių, siekiančių tapti sportiškais ir sveikais, motyvai gali būti priskiriami gydomiesiems.

B. L. Bredemeier ir D. L. Shields (2006) išskiria dar vieną motyvą, orientuotą i ego. Toks asmuo trokšta parodyti savo kompetenciją ar bent nepasirodyti esąs nekompetentingas. Autorių nuomone, šiuo atveju kompetencija suvokiama kaip geresni nei kitų žmonių gebejjimai ir todèl vertinami lyginant socialiniu požiūriu. Toki žmogu ypač motyvuoja troškimas pasirodyti geriau už kitus konkurencinëje situacijoje.

F. Lopez ir M. Garate (2007) atlikti tyrimai rodo, kad sporto klubo rinkodaros ir administravimo veiklos gali būti efektyvesnès, kai atsižvelgiama i vartotojų sociodemografines charakteristikas. Turėdami savo vartotojų duomenis ir atlikdami giluminę tyrimų analizę (angl. data mining) sporto klubo valdytojai gali efektyviau orientuoti savo veiklas, pavyzdžiui, organizuoti rèmimo (angl. promotion) kampanijas pritraukiant asmenis, turinčius didesnes pajamas, arba pratęsti sporto klubo darbo laiką, kad igyvendintų tų klientų lūkesčius, kuriems laikas yra svarbesnis rodiklis nei pinigai. Giluminiai savo vartotojų tyrimai gali būti naudingi norint išlaikyti esamus klientus, tobulinti pardavimo skatinimo veiklas, sustiprinti vartotoju apsisprendimą pirkti paslaugas, kurti pasiūlymus paslaugu vartotojams, palengvinti rinkodaros tyrimus, nustatyti geriausius sporto klubo paslaugu vartotojus (Chen, Lin, 2006). Norint kad sporto klube dažniau lankytųsi asmenys, kurie sportuoja nereguliariai, reikètų skirti daugiau pastangų moterims, darbininkams, jaunesnio amžiaus žmonėms pritraukti (Lopez, Garate, 2007).

Sporto organizacijai išsiaiškinus klientų motyvus, lūkesčius ir poreikius, gali atrodyti, kad darbas atliktas, tačiau tai yra tik pirmas žingsnis. Kitas etapas - nustatyti, kokie veiksniai lemia klientų pasitenkinimą ir norą likti būtent toje sporto organizacijoje.

Kliento pasitenkinimas - tai jo emocinę nuostatą kompanijos ar veiklos atžvilgiu nusakantis rodiklis (Adomaitytė, 2006; Bodet, 2006). Be to, sporto sektoriuje emociné nuostata yra ypač reikšminga, nes tai ji, priklausomai nuo teisingai suformuluotos komunikacinès žinutès, paskatina pasirinkti tam tikrą sportinę veiklą ir klubą, pradėti sportinę veiklą (Kang et al., 2011). Emocinę nuostatą, klientų lūkesčius dèl tam tikros sportinès veiklos ir aptarnavimo lygio formuoja nebūtinai 
ankstesnis patyrimas (ne tik toje pačioje organizacijoje), tai ir draugų, pažisstamų, kolegu atsiliepimai, rekomendacijos ar aprašai, pateikti vartotojams ivvairiuose leidiniuose, paslaugu kaina, patikimumas, personalo elgsena, rinkodaros strategijos elementai (reklamos kokybė, kiekis, asmeniniai pardavimai), organizacijos reputacija ir îvaizdis (Banytè, 2001; Bodet, 2006; Robinson, 2007; Kang et al., 2011). Klientai savo pasitenkinimą arba nepasitenkinimą gali reikšti dvejopai: išsakyti darbuotojams ir pažįstamiems, t. y. aktyviai ir pasyviai (Pajuodis, 2005). Vienas nepatenkintas klientas pasiguodžia šešiems artimiausiems asmenims, o šie informuoja vidutiniškai dar po septynis asmenis (Vanagas, 2004). Tačiau reikia atkreipti dėmesį, kad pasitenkimo kriterijai gali varijuoti pagal stiprumą ir pagrindinès sporto klubo paslaugos požiūriu būti esminiai ir periferiniai, o tai tiesiogiai veikia ịrenginio, žmogiškujų išteklių ir klientų valdymą (Bodet, 2006).

T. H. Sawyer, O. Smith (1999) išskiria šiuos su pasitenkinimu susijusius vartotoju motyvus pasirenkant sporto klubą: patogi vieta, greitas aptarnavimas, nesudėtinga nusipirkti reikalingas prekes, nèra labai daug dalyvių (neperpildytas klubas), paprasta pastatyti automobili, patraukli kaina, platus prekių asortimentas, siūlomos paslaugos, patrauklus ịrengimas, tinkama personalo kvalifikacija, paslaugu pirkimo galimybès, saugumas. Autoriai pateikia tokias svarbiausias sporto klubo klientų išlaikymo strategijas: kokybiška programa, klubo atmosfera, informavimas. L. Robinson (2007) papildo, kad naudingos ir vartotojų švietimo strategijos, taikomos susibūrimų metu, kai galima supažindinti vartotojus su siūlomomis paslaugomis ir padėti suformuoti realius lūkesčius.

Vartotojo pasitenkinimas ir organizacijos pelningumas yra labai susiję su kokybe (Kotler ir kt., 2003). Tačiau vertinti pasitenkinimą taikant vien kokybinius modelius negalima, nes sporto klubo lankytoju pasitenkinimui gali turèti ịtakos, pavyzdžiui, ir socialinė grupès sudėtis (Bodet, 2006). Vartotojų pasitenkinimas ir lojalumas priklauso nuo bendro vartotojų pasitenkinimo, suvoktos kokybės, informatyvumo, hedonizmo ir bendro priešinimosi pokyčiams. Tai yra esminiai veiksniai, lemiantys ilgalaiki sporto klubo išlikimą, ilgalaikę sėkmę, konkurencini pranašumą (Fasan, Agoro, 2007; Tsitskari et al., 2006; Bodet, 2012). Šias nuostatas galima papildyti dar viena - „vienos penktosios taisykle“: pritraukti naują klientą kainuoja penkis kartus brangiau negu išlaikyti esamą, nes reikia papildomų išlaidų reklamai ir kitiems veiksmams (Vanagas, 2004).

Kita labai svarbi sporto klubo kūrimo ar valdymo veikla yra organizacijos ívaizdžio ir reputacijos kūrimas. Paprastai įvaizdis suvokiamas kaip kažkas naujo ir laikino, kas priklauso nuo turinio ir konteksto, o reputacija - kaip kažkas ilgai besitęsiančio, atsiradusio bendru susitarimu ir nepaprasto. Tikejjimas ir pasitikejjimas yra pagrindiniai įvaizdžio komponentai, padedantys kurti ryšius su vartotojais. Tik gera ivvaizdi, kuriamą per teigiamas emocijas, ir reputaciją turintis sporto klubas gali tikètis, kad vartotojas pasirinks jo paslaugas ar taps lojaliu klientu (Parent, Foreman, 2007; Kang et al., 2011; Bodet, 2012).

Kadangi sporto organizacijos pelningumui turi itakos esamų klientų išlaikymas ir lojalumas, svarbiausiomis klubo valdymo veiklomis laikomos šios: paslaugu kokybès palaikymas ir gerinimas, bendro pasitenkinimo ir narystès perpirkimo valdymas, personalo paslaugumo, svetingumo, kompetencijos ir lojalumo didinimas, programų asortimento ir neiprastų ar papildomų individualių 
paslaugu kūrimas, automobilių stovėjimo vietų, patogumo ir švaros užtikrinimas, vaikų užimtumo organizavimas ir kt. (Westerbeek et al., 2006; Howat, 2007; Sawyer, Smith, 1999; Fasan, Agoro, 2007; Bodet, 2006; Robinson, 2007; Murray, Howat, 2002). Be to, būtina sukurti aukštą sporto klubo organizacinę kultūrą, sudaryti geidžiamo, patikimo, savito ir saugaus klubo ìvaizdị. Taip pat labai svarbu suteikti klubui išskirtinumo: pasiūlyti pilną konkurencini paslaugu paketą, pasirinkti gerą strateginę vietą (puikus gamtovaizdis, geras privažiavimas, sporto klubų trūkumas), sukurti stilingo klubo, kuriame yra ne tik sporto salè, ivaizdi. Ypač svarbu atsižvelgti i vartotoju poreikius ir laiku išsiaiškinti, kokių paslaugu jie pasigenda. Išsiaiškinti papildomus sporto (sveikatingumo) klubo klientų lūkesčius ir maksimaliai patenkinti jų poreikius padeda atliekami tyrimai.

Sporto klubo paslaugos gali būti tobulinamos ir atnaujinamos pagal poreikius. Kiekvienas klientas turi jaustis išskirtinis, sukurta palanki atmosfera visada trauks ji grižti ir naudotis teikiamomis paslaugomis. Sporto klubo išskirtinumą gali atskleisti konkurencinė analizė. Reikia nepamiršti, kad veikiantys sporto klubai savo geografinèje erdvejje jau yra užèmę tam tikrą rinkos dalį. Taigi sporto klubo išskirtinumui ir stiprioms konkurencinėms sritims nustatyti vadybininkai turi atlikti papildomus tyrimus, numatyti reikiamus veiksmus ir suplanuoti veiklas.

\section{IŠVADOS}

1. Reikiamos lyderio savybès - gebėjimas aiškiai apibrèžti užduotis, planuoti, organizuoti, kontroliuoti, vertinti, motyvuoti, rodyti pavyzdị ir kt. - gali būti išugdytos. Nuo efektyvaus vadovavimo priklauso imonès sėkmè, todèl sporto klubu vadovai, valdantys personala, tiesiogiai dalyvaujantys kuriant sporto paslaugas ir darantys tiesioginę itaką klientams, lyderio savybių ugdymą turètų priskirti prie ypač svarbių veiklų. Sporto klubų veikla orientuota i žmones, todèl žmogiškujų išteklių valdymas apima veiklas, susijusias ir su personalu, ir su klientais, ir su savanoriais. Pagrindinès personalo motyvavimo priemonès yra darbo užmokestis, saugumas, draugiškas kolektyvas, pripažinimas, tinkamas įvertinimas už atliktą darbą ir kt.

2. Tiriant vartotojų poreikius ir lūkesčius, susijusius su jų motyvais dalyvauti sportinèje veikloje, ir siekiant juos patenkinti svarbu išsiaiškinti vartotojų vertybių prioritetus, problemas bei sociodemografines charakteristikas ir remtis šiais duomenimis atliekant vadybines funkcijas. Klientų lūkesčių patenkinimas priklauso nuo paslaugų kokybės ir kainos santykio, personalo elgsenos, teigiamų emocijų ir klubo ivvaizdžio kūrimo, instruktorių skaičiaus ir individualaus dèmesio klientui, patrauklios ir patogios aplinkos, modernių i̇renginių. Papildomą vertę suteikia programų individualizavimas, patogi automobilių stovėjimo vieta, programų vaikams kūrimas, kvapų naudojimas, proginiai renginiai, lojalumo programos, priminimas apie besibaigiantį narystės terminą ir pan.

3. Rinkodaros požiūriu, pagrindiniai veiksniai, lemiantys sporto klubo plètros ir vartotoju poreikių dermę, yra prekès ženklo, asociacijų, i̇vaizdžio ir reputacijos kūrimas bei palaikymas, konkurencingos kainos, atitinkančios vartotojų poreikių patenkinimo kokybę, 
viešinimas rinkoje. Sporto organizacijos pelningumui turi įtakos esamų klientų ir personalo motyvavimas, lojalumo skatinimas, dalijimasis vertybèmis. Tai padeda siekti bendro pasitenkinimo, kurti pridėtinę vertę ir papildomas paslaugas, užtikrinančias sporto klubo išskirtinumą žmogiškujų išteklių ir rinkodaros veiklų prasme.

\section{LITERATŪRA}

1. Adomaitytė, J. (2006). Efektyvus klientu aptarnavimo kokybės valdymas padeda daugiau parduoti. Marketingas. Rinkos ivvaldymo menas, 9 (21), 42-48.

2. Appleby, R. C. (2003). Šiuolaikinio verslo administravimas. Vilnius: Charibdè.

3. Banytė, J. (2001). Meilès formulè. Efektyvaus klientų aptarnavimo sistemos elementai. Vadovo pasaulis, 7$8,40-42$.

4. Bodet, G. (2006). Investigating customer satisfaction in a health club context by an application of the tetraclasse model. European Sport Management Quaterly, 6 (2), 149-165.

5. Bodet, G. (2012). Loyalty in sporto participation services: An examination of the mediating role of psychological commitment. Journal of Sport Management, 26, 30-42.

6. Bredemeier, B. L., Shields, D. L. (2006). Sports and character development. Research Digest, President's Council on Physical Fitness and Sports, 7 (1), 1-8.

7. Brooks, C. M. (1994). Sports marketing: Competitive business strategies for sports. New Jersey: PrenticeHall, Englewood Cliffs.

8. Carrubba, L. Dealing with Employee Turnover. Club Industry. Internet link: http://fitnessbusinesspro.com/mag/fitness_dealing_employee_turnover/index.html [Accessed: 201310 28].

9. Chelladurai, P. (2001). Managing organizations. For Sport \& Physical activity. Holcomb Hathaway, Publishers.

10. Chen, C., Lin, Y. (2006). A new market research approach in sport-data mining. The Sport Journal, 9 (3), unpaginated.

11. Dževeckytė, R. (2007). Lojalumas - vadovo svajonè. Verslo naujienos. Prieiga per internetą: http://vz.lt/Default2.aspx?ArticleID=d48aa12f-56e9-48f4-ac58-57c048e93fe9 [žiūrèta: 201311 08].

12. Garrigou, A. (2008). Illusio in Sport. Sport in the Global Society. London and New York: Routledge Taylor \& Francis Group. P. 172-182.

13. Howat, G. (2007). Predictors of customer loyalty for aquatic and fitness centres. 12-th Congress European Association For Sport Management (pp. 309-312). EASM: Ghent

14. Kaliprasad, M. (2006). The Human Factor I: Attracting, Retaining, and Motivaiting Capable People. Cost Engineering, 48 (6), 20-26.

15. Kotler, P., Armstrong, G., Saunders, J., Wong, V. (2003). Rinkodaros principai. Kaunas: Poligrafija ir Informatika.

16. Lopez, F., Garate, M. (2007). The demand for sport: Sport consumption and participation models. Journal of Sport Mmanagement, 21, 103-122. Human Kinetics, Inc.

17. Marcinkutè, A., Ambrazevičius, M., Rainys, D. (2005). Kūno ¿̇vaizdžio ir daugiamatès antropometriniu rodikliu analizés sankiba. Prieiga per internetą: http://www.smd.mf.vu. 1t/index.php?page=antroptezes04) [žiūrèta: 20131108$].$

18. Pajuodis, A. (2005). Prekybos marketingas. Antras pataisytas ir papildytas leidimas. Vilnius: Eugrimas. 
19. Parent, M. M., Foreman, P. O. (2007). Organizational image and identity management in large-scale sporting events. Journal of Sport Management, 21, 15-40.

20. Robinson, L. (2007). The challenge of managing customer expectations of sport services: A theoretical model. 12-th Congress European Association For Sport Management (pp. 151-153). EASM: Ghent.

21. Sawyer, T., H., Smith, O. (1999). The management of clubs, recreation and sport. Champaign, Illinois: Sagamore Publishing.

22. Schlesinger, T., Nagel, S. (2013). Who will volunteer? Analysing individual and structural factors of volunteering in Swiss sport clubs. European Journal of Sport Science, 13 (6), 707-715.

23. Tsitskari, E., Tsiotras, D., Tsiotras, G. (2006). Measuring Service Quality in Sport Services. Total Quality Management, 17 (5), 623-631.

24. Westerbeek, H., Smith, A., Turner, P., Emery, P., Green, Ch., Leeuwen, L. (2006). Managing sport facilities and major events. Routledge, New York.

25. Woodard-Chavez, K. D. (2003). Reduce staff turnover, increase your profit. Club Industry, 19 (5), 21. Internet link: http://web.ebscohost.com/bsi/delivery?vid=8\&hid=9\&sid=9be00e79-fd31-4267-a6c1ef1538a0c0cc\%40SRCSM1 [Accessed: 201311 09]. 


\title{
COHERENCE OF SPORTS CLUBS DEVELOPMENT AND CONSUMER NEEDS: ASPECT OF RESEARCH INTERESTS
}

\author{
Diana Komskienė, Biruta Švagždienè \\ Lithuanian Sports University, Kaunas, Lithuania
}

\begin{abstract}
One of the main preconditions of successful coherence between the development of sports clubs and consumer needs is the satisfaction of consumers' needs and expectations by improving the quality of services. Quality of services develops customer loyalty, ensures the attraction of potential users, employee satisfaction, and the formation of a positive image in the market. On the basis of research results, the paper presents coherence factors of sports clubs development and consumer needs. It discusses to what extent this determines the peculiarities of activities. It is considered that one of the most important factors stimulating the development of sports clubs and organizations, competing with each other, maintaining or helping to conquer the markets, is the satisfaction of consumer needs. However, the needs of consumers of sports clubs are usually analysed through the dimensions of quality (Bodet, 2006). Quality creates the image of the sports clubs, and it has a direct impact on business productivity, profit growth and consumers' satisfaction. Research methods applied were the analysis of scientific literature, systemization and generalization. The research approach was qualitative. Content analysis was applied. The research emphasis was on the demand of sports clubs services, loyalty to the club, consumers' needs and motivation. The development of sports clubs is the consumer's perceived utility, which is created by the service providers' attempts, using a variety of communication efforts and promotion means. All services at sports clubs can be classified into three groups: 1) basic services, 2) additional peripheral services, and 3) supporting services, known as special and recreational services. Furthermore, research on the market should be further continued in order to better understand the expectations of consumers and to meet their needs.
\end{abstract}

Keywords: sports club, service, satisfaction, image, motivation. 


\title{
ГАРМОНИЧНОЕ РАЗВИТИЕ СПОРТИВНЫХ КЛУБОВ И ПОТРЕБИТЕЛЬСКОГО СПРОСА: АСПЕКТ НАУЧНЫХ ИНТЕРЕСОВ
}

\author{
Diana Komskienè, Biruta Švagždienè \\ Литовский университет спорта, Каунас, Литва
}

\section{РЕЗЮМЕ}

Одним из основных условий гармоничного и взаимосвязанного развития спортивных клубов и потребительского спроса является удовлетворение потребностей и ожиданий потребителей по повышению качества услуг. Качество обслуживания оказывает влияние на лояльность клиентов, обеспечивая привлечение потенциальных пользователей, удовлетворенности сотрудников и формирование положительного имиджа на рынке. В статье, согласно данным проведенного исследования, представлены факторы когерентности развития спортивных клубов и потребностей потребителей. Расматривается, в какой степени это влияет на результаты деятельности. Считается, что одним из наиболее важных факторов, содействующих развитию спортивных клубов и конкуренции между организациями, выживанию и завоевыванию рынка является удовлетворенность потребителей. Тем не менее спортивные клубы потребности потребителей обычно анализируют с точки зрения качества (Bodet, 2006). Качество формирует имидж спортивных клубов, оказывает непосредственное влияние на продуктивность деятельности, рост прибыли и удовлетворенность пользователей. Цель статьи - выявить когерентность развития спортивного клуба и потребительского спроса в аспекте научных интересов. Методы исследования: анализ источников научной литературы, систематизация и обобщение. В ходе исследования проведено качественное исследование, применен содержательный анализ. При проведении исследования акцент делался на потребность предоставляемых услуг, лояльность клубу, потребительский спрос и мотивацию. Развитие спортивных клубов - это понимаемая полезность услуги пользователем, которая создается усилиями поставщика услуг с использованием различных пропагандистских средств и мер поддержки. Все услуги спортивных клубов могут быть разделены на три группы: 1) основные услуги, 2) дополнительные периферийные услуги, 3) дополнительные, или специальные, услуги, а также услуги по организации отдыха. Кроме того, следует регулярно исследовать рынок, чтобы лучше понимать ожидания пользователей и таким образом удовлетворять их потребности.

Ключевые слова: спортивный клуб, услуга, удовлетворение, имидж, мотивация. 